\title{
Gastric Inhibitory Polypeptide (GIP), Gastrin and Insulin: Response to Test Meal in Coeliac Disease and after Duodeno-Pancreatectomy
}

\author{
W. Creutzfeldt, R. Ebert, R. Arnold, H. Frerichs and J. C. Brown* \\ Division of Gastroenterology and Metabolism, Department of Medicine, University of Göttingen, \\ Göttingen, Federal Republic of Germany
}

\begin{abstract}
Summary. The response of serum immunoreactive gastric inhibitory polypeptide (IR-GIP), gastrin (IRG) and insulin (IRI) to a mixed standard meal was measured in 15 controls, 6 patients with coeliac disease, 26 patients with chronic pancreatitis and $6 \mathrm{pa}-$ tients with chronic pancreatitis and partial duodenopancreatectomy (Whipple's procedure). Serum levels of IR-GIP, IRG and IRI were significantly reduced in patients with coeliac disease. The serum glucose increase was significantly smaller only during the first hour after the meal. Since small intestinal GIP-and G-cells are situated mainly in the glands of duodenal and jejunal mucosa their absolute number is not significantly reduced in coeliac disease. It is suggested that the release of IR-GIP and duodenal IRG is influenced by the rate of absorption of nutrients. In patients with chronic pancreatitis the IR-GIP release is significantly greater than in controls, the IRG release normal and the IRI response delayed. After Whipple's procedure the IR-GIP response is increased significantly while the IRG secretion is abolished. This demonstrates that the duodenum is not necessary for GIP release and that pancreatic and jejunal gastrin are without clinical significance.
\end{abstract}

Key words: GIP, gastrin, insulin, incretin, coeliac disease, duodeno-pancreatectomy, chronic pancreatitis.

The enteral factor responsible for the greater insulin release after oral glucose ingestion or intraduodenal glucose infusion compared with an i.v. glucose infusion has not yet been defined [4]. Of the different gastrointestinal hormones and candidate hormones of the gut, gastric inhibitory polypeptide (GIP) fulfils all

\footnotetext{
* present address: Department of Physiology, The University of British Columbia, Vancouver B. C., Canada V6T 1 W5.
}

criteria necessary for the rôle of "incretin". GIP was released after ingestion of glucose and fat [2,3,7,14]; intravenous infusion of very highly purified GIP, in doses producing peak plasma levels in the range attained after glucose ingestion, resulted in potentiation of the glucose induced insulin release and improvement in glucose tolerance [6, 14].

Recently, it has been questioned that the incretin effect can be attributed largely to GIP [17], because the incretin effect was preserved in patients after duodeno-pancreatectomy (Whipple's operation), i.e. after resection of the antrum, the duodenum, the head of the pancreas and the proximal part of the jejunum. Since it has been suggested that GIP is produced "predominantly in the duodenum and, to a lesser extent, in the jejunum" [16], the preservation of the incretin effect in patients with Whipple's procedure could disqualify GIP as an incretin candidate. This question could be settled by direct measurement of serum GIP levels after a meal in patients after duodeno-pancreatectomy. The role of the intact small bowel mucosa in GIP production can be elucidated by comparing GIP release to a test meal in normal persons with that of patients with coeliac disease, i.e. mucosal atrophy due to gluten-enteropathy.

The aim of this investigation was to study GIP release after a test meal under these different anatomical conditions and to compare the changes in serum immunoreactive GIP (IR-GIP) levels with those of immunoreactive gastrin (IRG), immunoreactive insulin (IRI) and glucose.

\section{Material and Methods}

\section{a. Subjects}

The investigations were performed in 15 controls, 6 patients with coeliac disease, 6 patients with duodenopancreatectomy and 26 patients with chronic pan- 
creatitis. Informed consent was obtained from all subjects.

Controls. Fifteen healthy, normal volunteers (4 females, 11 males) with a mean age of 27 years (range 20 to 39 ) served as controls. These subjects were within $10 \%$ of their ideal body weight (mean weight $70.4 \mathrm{~kg}$ ) and had normal oral glucose tolerance.

Coeliac Disease. Six patients with coeliac disease were studied ( 5 females, one male). Their ages were $30,38,39,60,60$ and 78 years. The average deviation from ideal body weight was $-14 \%$. The diagnosis had been confirmed by mucosal biopsy. All patients except one had been on a gluten-free diet for three to six months. However, the remission was incomplete and biopsies performed at the time of the test meal still revealed subtotal villous atrophy in all cases.

Partial Duodeno-Pancreatectomy. Six male patients (ages 24, 26, 35, 40, 49 and 55 years), who had undergone Whipple's operation because of pancreatic pseudocysts or obstruction of the pancreatic duct in the course of chronic pancreatitis, were studied. The average deviation from ideal body weight was $-12 \%$. The test was performed at least three months after the operation. Faecal fat content in three patients was below $12.0 \mathrm{~g} / 24 \mathrm{~h}$ and between $25-50 \mathrm{~g} / 24 \mathrm{~h}$ in the other three. Two patients had a normal oral GTT, three had chemical and one an insulin-dependent diabetes. Two patients with total duodenopancreatectomy were also studied (one female, age 43 , one male, age 56 years).

Chronic Pancreatitis. The findings in the patients with Whipple's procedure were compared with a group of 26 patients with chronic pancreatitis, because all operations had become necessary in the course of chronic pancreatitis. The mean age of these patients $(6$ females, 20 males) was 42 years (range 21-62). The average deviation from ideal body weight was $-11 \%$. The diagnosis of pancreatitis was based on grossly abnormal pancreatic bicarbonate and enzyme responses after secretin and pancreozymin stimulation in all cases. In addition, most cases had steatorrhoea and/or radiologically ascertained pancreatic calcification. One quarter of the patients had a normal oral GTT, one quarter overt diabetes and half were chemical diabetics.

\section{b. Test Meal}

After an overnight fast, each subject was given $550 \mathrm{ml}$ of a test meal which was ingested within $10 \mathrm{~min}$. The test meal consisted of $400 \mathrm{ml}$ Dextro ${ }^{\circledR} \mathrm{O}$. G. T., containing $18 \mathrm{~g}$ glucose, $14 \mathrm{~g}$ maltose, $12 \mathrm{~g}$ maltotriose, 56 g oligosaccharides, corresponding to $100 \mathrm{~g}$ rapidly absorbable glucose (Pomps GmbH, Heilbronn) $100 \mathrm{ml} \mathrm{cream} \mathrm{(containing} 30 \%$ fat) and $100 \mathrm{~g} \mathrm{Molico}^{\circledR}$
Instant (Nestle, GmbH, Lindau), containing $36 \mathrm{~g}$ protein and $52 \mathrm{~g}$ lactose. This test meal contained 1031 calories. The osmolarity was $1280 \mathrm{mosmol} / \mathrm{l}$. A catheter was placed in the cubital vein and kept patent by slow infusion of saline. Blood samples were drawn fasting ( 3 samples) and $15,30,45,60,90,120,150$, $180,210,240,270$ and $300 \mathrm{~min}$ after ingestion of the test meal. No difference was seen when the blood samples were immediately placed on ice or kept at room temperature up to five hours. The samples were centrifuged at room temperature and five aliquots of each serum sample frozen and stored at $-20^{\circ} \mathrm{C}$. This was necessary because after thawing and refreezing about $70 \%$ of the immunoreactive GIP was destroyed.

\section{c. Laboratory Analysis}

IRI, IRG and IR-GIP were determined in duplicate on each sample within four weeks after the test. Serum glucose was measured in duplicate on each sample by the glucose oxidase method immediately after separating the serum. Serum IRI was determined using human insulin as a standard [13]. Serum IRG was estimated as described previously [12], using antiserum 118/2/3.

IR-GIP was measured by the method described by Kuzio et al. [11], with minor modifications. The GIPantiserum used was raised in guinea pigs and the same as used in the original description of the assay (11). GIP was labelled with ${ }^{125} \mathrm{I}$ by the chloramine T technique [8]. ${ }^{125} \mathrm{I}$-GIP and free ${ }^{125} \mathrm{I}$ were separated on a Sephadex G- 25 column $(0.6$ by $32 \mathrm{~cm})$. The fractions showing the least damage were used in the assay. The specific activity of ${ }^{125} \mathrm{I}$-GIP was calculated to be in the range of $90-150 \mathrm{mCi} / \mathrm{mg}$ for the various iodinations. Non-specific binding within the assays ranged from 5 to $12 \%$. ${ }^{125} \mathrm{I}$-GIP was stored at $-20^{\circ} \mathrm{C}$ after addition of $0.1 \%$ bacitracin; in the assay the concentration of bacitracin never exceeded $0.05 \%$. ${ }^{125} \mathrm{I}$-GIP showing damage in excess of $14 \%$ was not used in the assay.

Standard curves were set up with triplicate determinations and unknown samples in duplicate. Incubation was performed at $4{ }^{\circ} \mathrm{C}$ for $48 \mathrm{~h}$ in siliconized glass tubes. The final volume of the incubation mixture was $1 \mathrm{ml}$, consisting of $100 \mu \mathrm{l}$ of ${ }^{125} \mathrm{I}$-GIP containing about $4 \times 10^{3} \mathrm{CPM}, 100 \mu \mathrm{l}$ of standard GIP or unknown serum samples and $700 \mu \mathrm{l}$ of diluent buffer $(0.04 \mathrm{M}$ phosphate buffer, $\mathrm{pH} 6.5 ; 10 \%$ outdated human plasma which was extracted with $5 \%$ charcoal and showing no detectable GIP; $0.625 \%$ Aprotinin (20000 $\mathrm{KIE} / \mathrm{ml}$ as Trasylol ${ }^{\circledR}$, Bayer, Leverkusen)). The lower limit of sensitivity of the assay was between 5 to 12.5 $\mathrm{pg} / 100 \mu \mathrm{l}$ of GIP; values of less than $5 \mathrm{pg} / 100 \mu \mathrm{l}$ were arbitrarily considered as $5 \mathrm{pg}$ for statistical analysis. 
Table 1. Integrated response (180 min) of IR-GIP, IRG, IRI and glucose to a test meal in controls, patients with coeliac disease, chronic pancreatitis and chronic pancreatitis with duodeno-pancreatectomy (Whipple's procedure)

\begin{tabular}{|c|c|c|c|c|c|c|c|c|}
\hline & $\begin{array}{l}\text { IR-GIP } \\
\mathrm{ng} / \mathrm{ml} \cdot 180 \mathrm{~min}\end{array}$ & & $\begin{array}{l}\mathrm{IRG} \\
\mathrm{ng} / \mathrm{ml} \cdot 180 \mathrm{~min}\end{array}$ & & $\begin{array}{l}\text { IRI } \\
\mathrm{mU} / \mathrm{ml} \cdot 180 \mathrm{mi}\end{array}$ & & $\begin{array}{l}\text { glucose } \\
\mathrm{g} / 100 \mathrm{ml} \cdot 180\end{array}$ & $\min$ \\
\hline $\begin{array}{l}\text { Controls } \\
(\mathrm{n}=15)\end{array}$ & $106.2 \pm 9.4$ & \multirow[b]{2}{*}{$<0.005$} & $6.4 \pm 1.4$ & \multirow[b]{2}{*}{$<0.025$} & $8.7 \pm 0.9$ & \multirow[b]{2}{*}{$<0.05$} & $3.8 \pm 0.5$ & \multirow[b]{2}{*}{ n.s. } \\
\hline $\begin{array}{l}\text { Coeliac disease } \\
(\mathrm{n}=6)\end{array}$ & $17.1 \pm 2.6$ & & $2.2 \pm 0.4$ & & $4.9 \pm 0.9$ & & $3.2 \pm 0.4$ & \\
\hline $\begin{array}{l}\text { Chronic pancreatitis } \\
(\mathrm{n}=26)\end{array}$ & $150.3 \pm 14.1$ & \multirow[b]{2}{*}{$<0.025$} & $7.3 \pm 0.9$ & \multirow[b]{2}{*}{$<0.005$} & $4.1 \pm 0.6$ & \multirow[b]{2}{*}{ n.s. } & $21.5 \pm 3.1$ & \multirow[b]{2}{*}{$<0.01$} \\
\hline $\begin{array}{l}\text { Whipple's } \\
\text { procedure } \\
(\mathrm{n}=6)\end{array}$ & $455.0 \pm 90.2$ & & 0.0 & & $5.8 \pm 1.2$ & & $33.1 \pm 5.7$ & \\
\hline
\end{tabular}

Non-specific binding was estimated for each subjects serum and used in the calculation of the amount of immunologically active GIP in the unknown samples. Known standards were added to charcoal-treated serum to yield a final concentration of $200 \mathrm{pg} / 100 \mu \mathrm{l}$ serum and measured at the beginning and at the end of the assay. The recovery was $95.6 \pm 7.2 \%$ at the beginning and $108.2 \pm 5.6 \%$ at the end of the assay (mean and SEM of 92 assays). Due to decreased sensitivity at lower IR-GIP levels found in fasting, inter-assay variance was $24.6 \%$ for fasting serum levels of IR-GIP and $14.5 \%$ for serum levels after stimulation.

\section{d. Immunohistology}

Jejunal mucosa from 4 patients with coeliac disease and 4 subjects with histologically normal mucosa were investigated. All biopsies were obtained with a Crosby capsule for diagnostic purposes. Duodenal mucosa of 2 patients with insulinoma who underwent duodenopancreatectomy were also investigated. The tissue samples were fixed in Bouin's fluid and embedded in paraffin. Five $\mu$ thick sections, cut vertically to the surface, were stained for GIP using the peroxidase labelled antibody technique as described previously for gastrin [5]. The GIP-antiserum was the same as used in the radioimmunoassay.

\section{e. Statistical Analysis}

All values are presented as means \pm SEM. Results were analyzed using standard statistical methods. Student's " $t$ " test for unpaired values was performed to compare results between the normal volunteers and the patients with coeliac disease and between the patients with chronic pancreatitis with and without duodeno-pancreatectomy. Integrated responses to the test meal for serum glucose, IR-GIP, IRG and IRI were calculated from summation of the products of the mean serum concentration during each time period, multiplied by the number of minutes in the time period minus the product of the basal value multiplied by the total number of minutes after a test meal [18].

\section{Results}

\section{a. Coeliac Disease Versus Controls (Fig. 1)}

Serum levels of IR-GIP rose sharply within the first 30 min following ingestion of the test meal, increased further during the next two hours and remained at this high level for at least $5 \mathrm{~h}$. Serum IRG levels also increased immediately after the test meal and remained at a high level until the end of the observation, suggesting that the stomach still contained food $5 \mathrm{~h}$ after ingestion of the meal. Serum IRI peaked at $\mathbf{3 0}$ min after the test meal and decreased thereafter without reaching fasting levels after $5 \mathrm{~h}$.

The shape of the glucose curve was nearly identical with the IRI curve.

In the patients with coeliac disease the response of the hormones to the test meal was different from the controls. IR-GIP hardly increased. IRG and IRI increased less than in the controls and also the increase of serum glucose was less. The differences between controls and patients with coeliac disease reached statistical significance at all points of the curve for IR-GIP, at many points for IRG and IRI, but only during the first hour for serum glucose.

The statistical evaluation of the integrated responses (Table 1) revealed highly significant differences between controls and coeliac disease for IRGIP and IRG and significant differences for IRI. However, the integrated glucose response was not significantly different. 

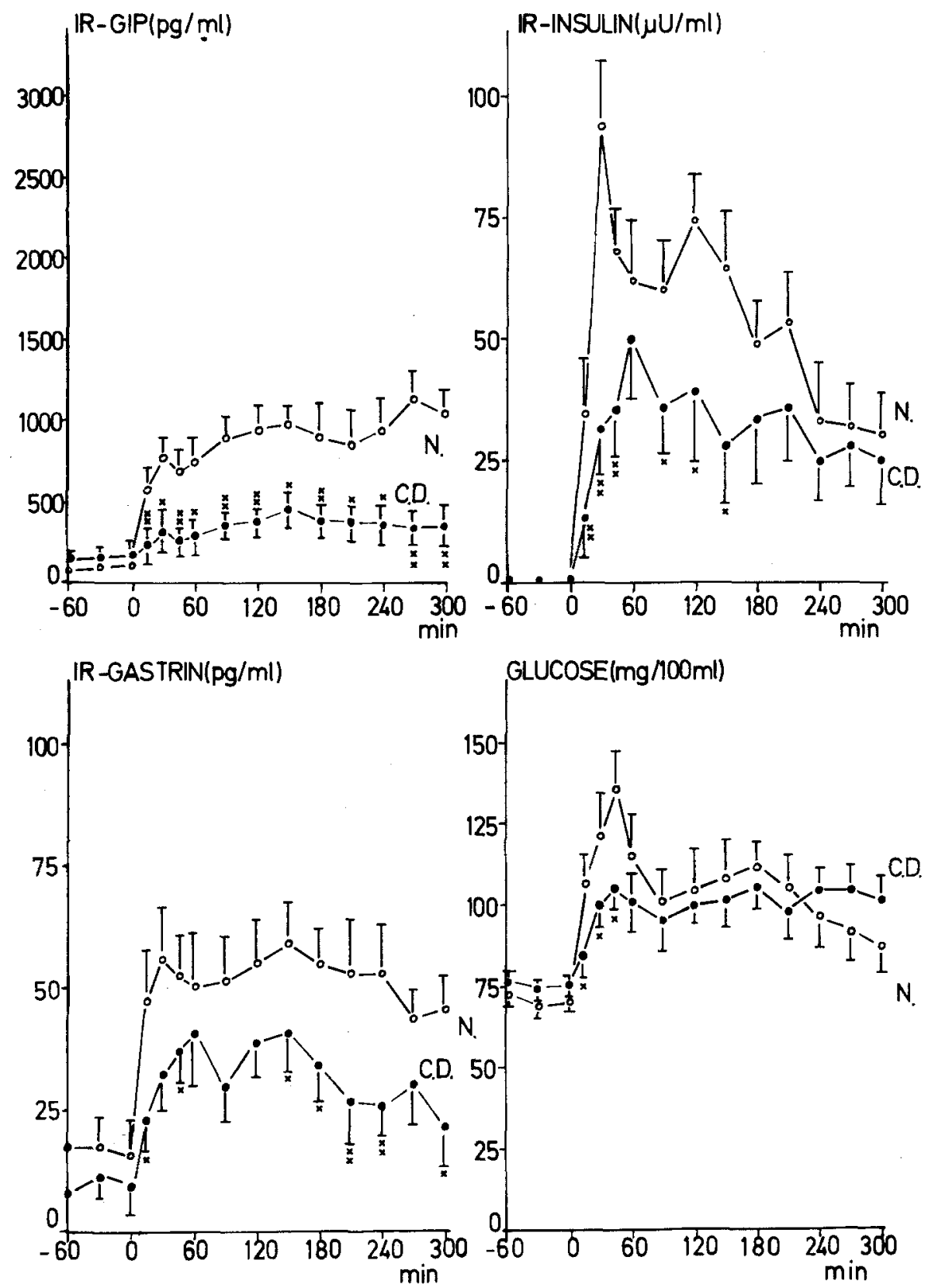

Fig. 1. Increase of serum levels of immunoreactive GIP, gastrin and insulin and of glucose in 15 normals (No- 0 ) and 6 patients with coeliac disease (C. D. $\bullet$ ) after a mixed high caloric test meal given at $0 \mathrm{~min}$. Significant differences are indicated $(*=p<0.05 ; * *=p<0.01)$

b. Comparison in Patients with Chronic Pancreatitis with and without Duodeno-Pancreatectomy (Fig. 2)

In patients with chronic pancreatitis fasting serum levels of IR-GIP were higher than in controls. However, due to the large variance this difference was not significant. The serum levels of IR-GIP rose sharply within the first $30 \mathrm{~min}$ following the ingestion of the test meal and remained at the same level until the end of the experiment $(5 \mathrm{~h})$. These levels were higher than in controls (Fig. 1).

The increase in the IRG levels was not greatly different from the controls. The IRI levels increased only slowly and remained far below the levels of the controls (Fig. 1) despite higher serum glucose values.

In the six patients with Whipple's operation the response of the hormones to the test meal was different. The IR-GIP reached much higher levels during the first three hours after food ingestion and decreased thereafter. The serum IRG was not measurable before and after the test meal, indicating complete removal of the gastrin-producing part of the stomach and duodenum. The IRI increased slowly, but to higher values and so did the serum glucose.

The differences between patients with chronic pancreatitis with and without Whipple's procedure 

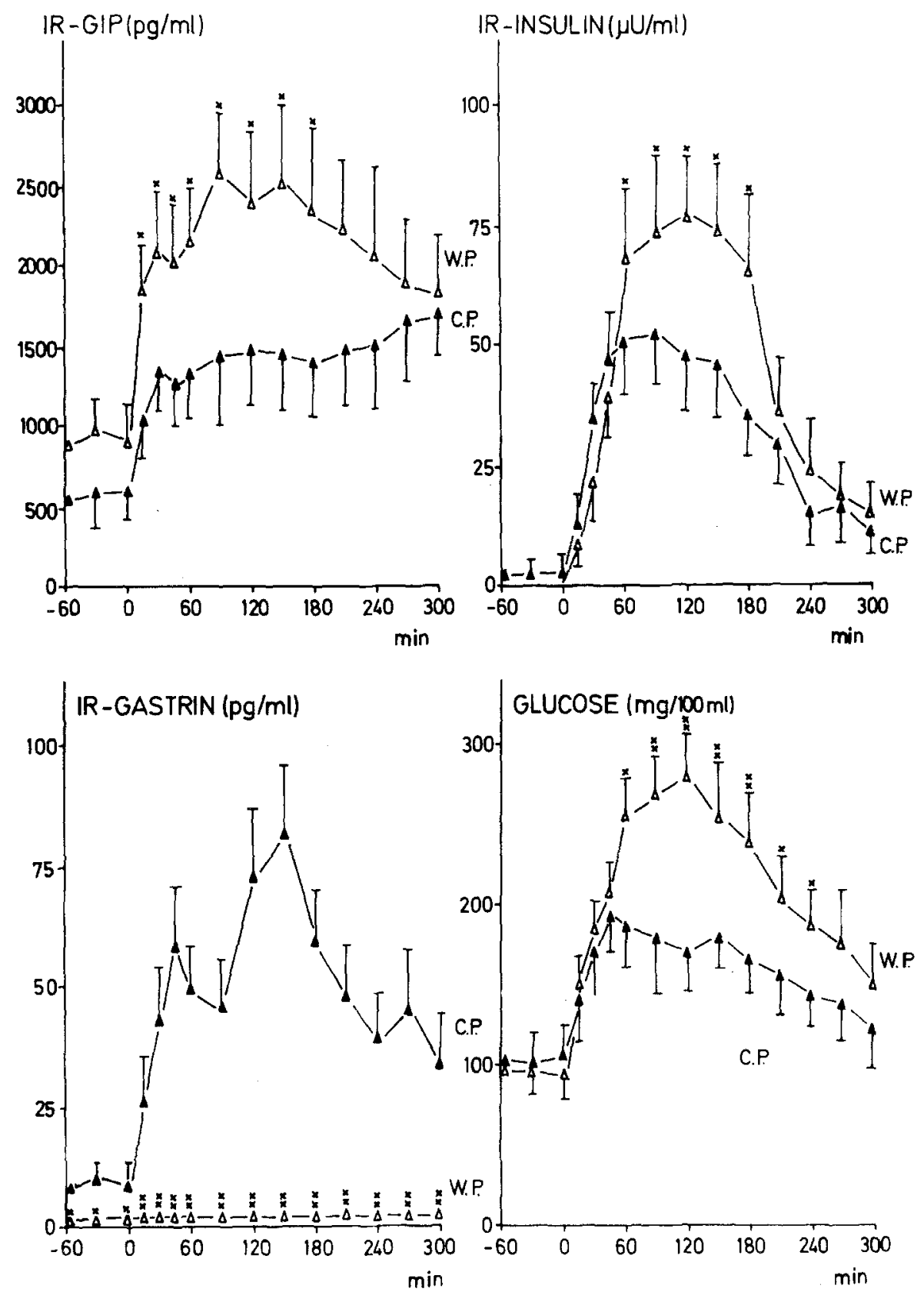

Fig. 2. Increase of serum levels of immunoreactive GIP, gastrin and insulin and of glucose in 26 patients with chronic pancreatitis (C. P.^s) and 6 patients with chronic pancreatitis and partial duodeno-pancreatectomy (Whipple's procedure) (W. P. $\triangle \triangle$ ) after a mixed high caloric test meal given at $0 \mathrm{~min}$. Significant differences are indicated $(*=p<0.05 ; * *=p<0.01)$

reached statistical significance at all points for IR-GIP and IRG while for IRI and glucose only in the middle part of the curve.

The statistical evaluation of the integrated responses (Table 1) revealed highly significant differences between patients with chronic pancreatitis with and without Whipple's procedure for IR-GIP, IRG and glucose, but not for IRI. The two patients with total pancreatectomy had no measurable IRI levels before and after the test meal. The IR-GIP response was greater than in the controls, but below the mean values of the six patients with partial duodeno-pancreatectomy (integrated IR-GIP response 227.1 and $211.9 \mathrm{ng} / \mathrm{ml} \cdot 180 \mathrm{~min})$.

\section{c. Immunohistology}

In the normal duodenal and jejunal mucosa fixed in Bouin's fluid cells reacting very distinctly with antiGIP serum were found. Only very few of these cells were situated in the epithelial layer of the villi. The majority of the GIP cells were found in the lower part, 


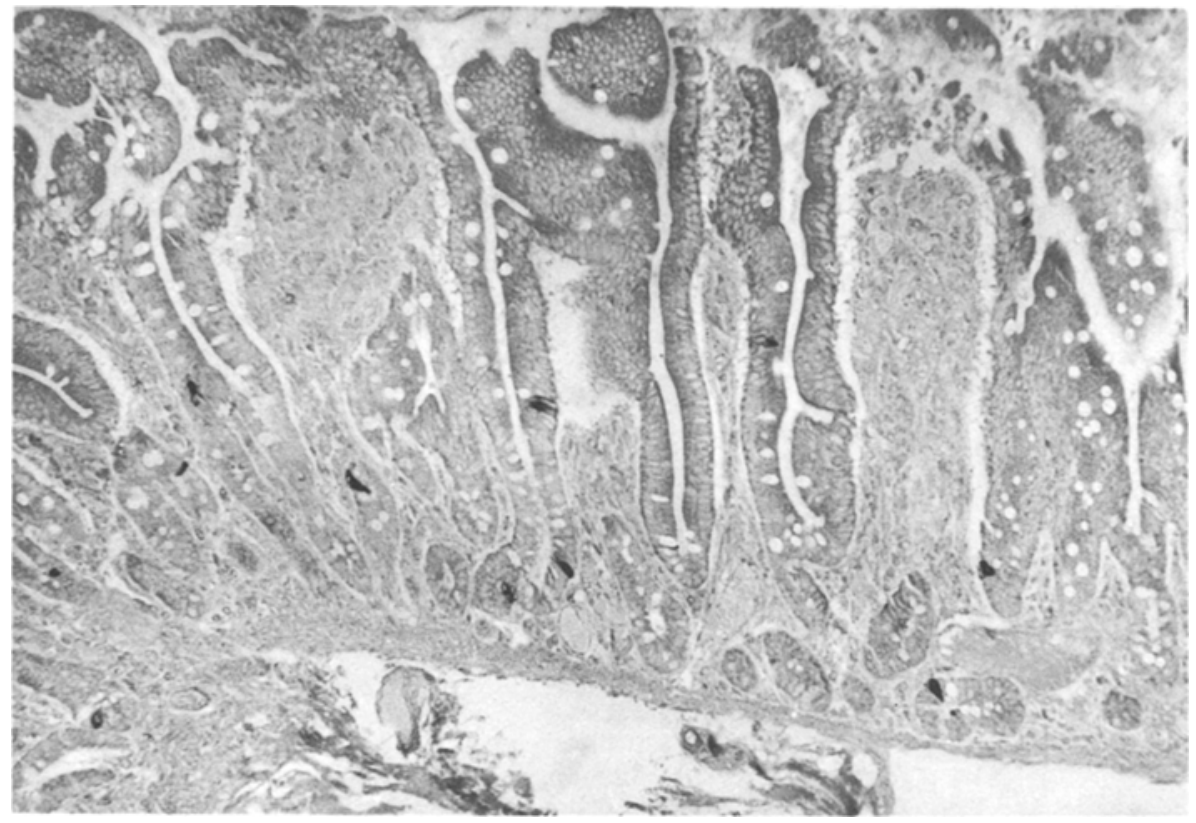

Fig. 3. GIP cells (black) in the epithelium of the lower and middle part of the crypts. Normal human jejunal mucosa. Bouin fixation. Paraffin embedding. Incubation of $1 / 20$ diluted anti-GIP serum; after washing incubation with $1 / 50$ diluted peroxidase labelled anti-rabbit- $\gamma$-globulin from sheep. $\times 160$

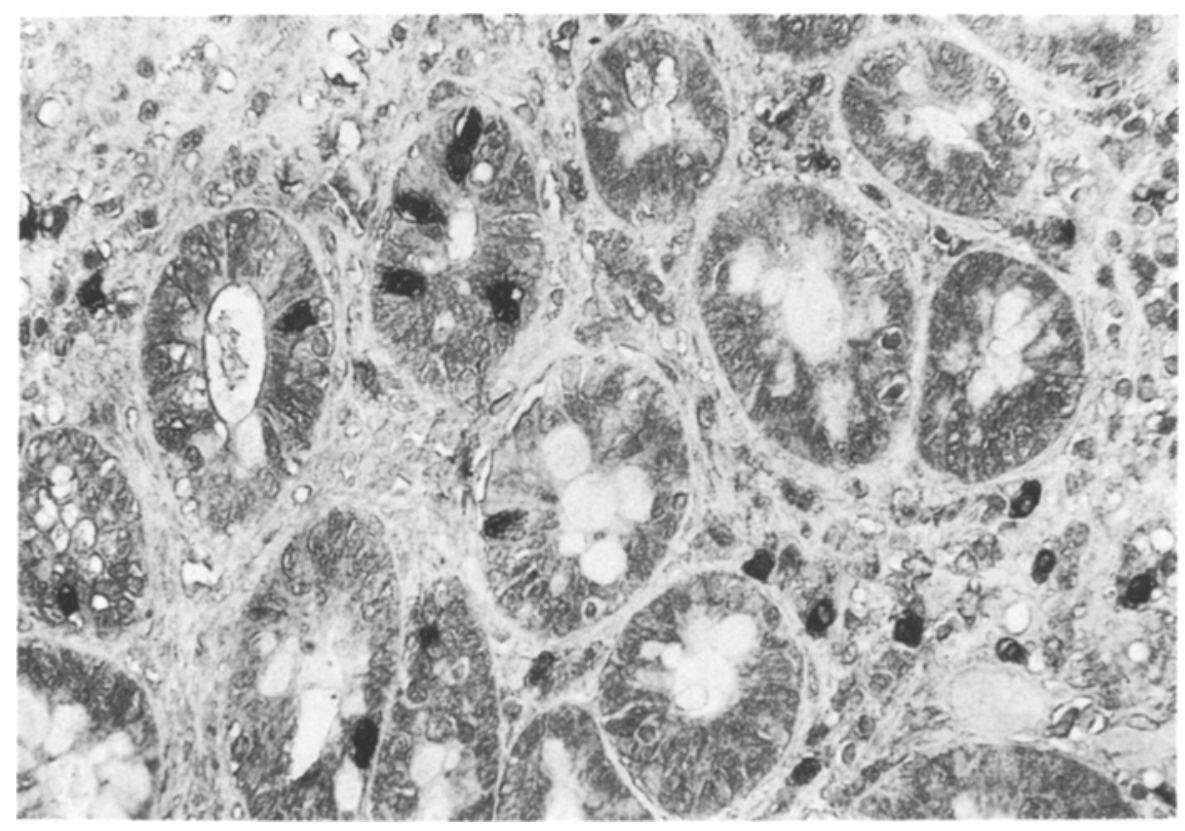

Fig. 4. Eight GIP cells (black) in the jejunal glands of a patient with coeliac disease. Technique as in fig. $3 . \times 400$

up to the middle zone of the mucosal crypts (Fig. 3). The jejunal mucosa of the patients with coeliac disease revealed subtotal villous atrophy. However, the mucosal glands were well preserved and contained numerous GIP-cells (Fig. 4). In the bottom of the glands the GIP-cells seemed to be even more frequent than in the normal mucosa. The small number of cases did not permit a morphometric analysis. However, the general impression was that the loss of GIP-cells by the villous atrophy was compensated by the rather large number of GIP-cells in the glands.

\section{Discussion}

Release of IR-GIP has been described in man and dog after oral ingestion of glucose [2,3,14], galactose [3], fat $[2,3,7,14]$ and leucine [3], while meat or Bovril ${ }^{\circledR}$ 
did not stimulate IR-GIP [3]. The increase of serum IR-GIP after fat intake is greater and more prolonged than after glucose ingestion $[2,3,14]$. It has been suggested that different secretagogues release structurally different IR-GIP which are immunologically identical but exert different biological actions [3,14]. To achieve maximal release of these possibly different molecular forms of GIP a standard test meal containing glucose, lactose, fat and protein was given.

The mixed test meal induced a rapid IR-GIP increase in all cases which usually lasted longer than $5 \mathrm{~h}$. Under the same test conditions IRG, IRI and glucose increased rapidly and remained elevated for $5 \mathrm{~h}$, i.e. for as long as the levels were investigated. This suggests very slow emptying of the test meal from the stomach.

The finding of a smaller increase of serum levels for IR-GIP, IRG and IRI after a test meal in patients with coeliac disease compared with healthy controls (Fig. 1) can be explained in two ways: 1 . The villous atrophy characteristic of coeliac disease leads to a reduction in GIP-cells and G-cells in the duodenal and jejunal mucosa; 2 . the decreased rate of absorption in coeliac disease leads to less stimulation of intestinal hormone and insulin release.

The simplest explanation for the significantly lower GIP and IRG response of the patients with coeliac disease to a test meal would be the reduced number of endocrine cells in the atrophic duodenal and jejunal mucosa. In fact, all coeliac patients had subtotal villous atrophy at the time of the investigation. However, the number of GIP-cells in the villi of normal duodenal and jejunal mucosa is small compared to those in the glands. This finding is in agreement with an earlier report of Polak et al. [16]. Also the G-cells are mainly found in the crypts of the duodenal mucosa and much less frequently in the epithelium of the villi (unpublished observations).

Thus, villous atrophy would result only in an insignificant numerical reduction of duodenal G-cells or duodenal and jejunal GIP-cells. This reduction could well be compensated by the apparently increased number of GIP-cells in the glands of the jejunal mucosa. However, the small number of patients with coeliac disease investigated in this study and the lack of morphometric analysis do not allow any conclusion as to a possible hyperplasia of GIP-cells in coeliac disease, as suggested for secretin cells [15]. At the moment it would appear that the absolute number of GIP-cells is not significantly reduced in coeliac disease. Therefore, the poor response of IR-GIP and IRG in patients with coeliac disease may not be simply the result of a decreased number of intestinal endocrine cells.

The trigger mechanism for the hormone release from intestinal endocrine cells is still unknown. One possibility could be that chemical signals are received by the microvilli protruding into the lumen of the glands. However, as this mechanism is intact in coeliac disease the significantly reduced hormone release could not thus be explained. The other alternative would be regulation of intestinal hormone release by the rate of absorption of nutrient, a mechanism which could serve to quantitate the incoming load [2]. In coeliac disease absorption is defective and malabsorption was still present in all coeliac patients at the time of investigation. If the GIP release is dependent on the rate of nutrient absorption, the lower increase of IRGIP can be understood.

The significantly lower IRG release in coeliac disease indicated a reduced secretion of duodenal gastrin, because the antrum is not involved in coeliac disease. Again, one cannot decide if a loss of duodenal $\mathrm{G}$-cells or decreased absorption are responsible for this. However, the finding demonstrates that duodenal gastrin contributes to the postprandial serum IRG levels in subjects with an intact stomach. The role of duodenal gastrin has been demonstrated previously only in antrectomized patients [18].

The lower IRI release in coeliac disease can be explained by the reduced glucose absorption and/or the lower GIP release, assuming that GIP is the main "incretin". Only animals experiments can decide this question.

The indication for partial duodeno-pancreatectomy in all patients was complications in the course of chronic pancreatitis. Therefore, the serum levels of hormones and glucose after the test meal in these patients were compared with the results in patients with chronic pancreatitis. These patients had an exaggerated IR-GIP response, a normal IRG release, an impaired IRI secretion and a greater glucose increase after the standard test meal compared with controls. The impaired IRI response to multiple stimuli is well known in patients with chronic pancreatitis $[1,9]$ and explains the pathological glucose tolerance. Half of the patients studied had chemical and one quarter overt diabetes. The normal serum IRG response to a test meal in this condition corresponds to the reported normal gastrin response to arginine infusion [10]. The increased IR-GIP response of patients with chronic pancreatitis is not related to the degree of steatorrhoea and only partially to the severity of the diabetes (unpublished observations).

The significantly greater serum IR-GIP response of patients with chronic pancreatitis after duodenopancreatectomy clearly demonstrates that GIP is produced in large amounts in the jejunum which supports its candidacy for "incretin". There could be two explanations for the greater IR-GIP release in patients with Whipple's procedure: 1 . the rapid passage of the test meal through the gastrojejunostomy into the small 
bowel could be a strong mechanical or chemical stimulus; also the partial denervation of the small bowel could have altered the reactivity of GIP cells; 2 . a decrease of the insulin reserve after duodeno-pancreatectomy could lead to a reduced feedback inhibition of GIP secretion by IRI release [2]. This explanation is not supported by the actual findings in that the IRI response was even higher than in the nonoperated patients with chronic pancreatitis (Fig. 2). Also in the two patients with total pancreatectomy investigated in addition, who had no measurable IRI levels, the IRGIP response was below the mean of the patients with partial pancreatectomy.

As reported previously [17] IRG levels were not measurable in the fasting state and postprandially in patients with Whipple's procedure. Since the tail of the pancreas is preserved during this operation it can be concluded that pancreatic gastrin is without clinical significance in man. The large postprandial IR-GIP release, without a simultaneous IRG response, also demonstrates that IRG is not necessary for IR-GIP secretion.

\section{In Conclusion}

The release of IR-GIP, IRG and IRI to a standard meal is decreased in patients with coeliac disease. In patients with duodeno-pancreatectomy the IR-GIP release is increased while IRG secretion is abolished and IRI release is not significantly different from unoperated patients with chronic pancreatitis. The data suggest that the rate of absorption of nutrients, the capacity to secrete insulin and possibly also the innervation of the small intestine, influence the release of GIP.

Acknowledgements. This work was supported by the Deutsche Forschungsgemeinschaft, Bonn-Bad Godesberg, grant $\mathrm{Cr} 20 / 7$ (20/12) and grant 41/3208-Brown. The authors want to thank Mrs. K. Illmer, Miss E. Bothe, Mrs. B. Hillebrecht and Miss A. Nesslinger for their expert technical assistance.

\section{References}

1. Bank, S., Jackson, W. P. U., Keller, P., Marks, I. N.: Serum insulin response to glucose in pancreatic diabetes. Postgrad. med. J. 44, 214-217 (1968)

2. Brown, J. C., Dryburgh, J. R., Ross, S. A., Dupré, J.: Identification and actions of gastric inhibitory polypeptide. Recent Progr. Hormone Res. 31, 487-532 (1975)

3. Cleator, I. G. M., Gourlay, R. H.: Release of immunoreactive gastric inhibitory polypeptide (IR-GIP) by oral ingestion of food substances. Amer. J. Surg. 130, 128-135 (1975)

4. Creutzfeldt, W.: Insulin-releasing factors of the gastrointestinal mucosa (incretin). Gastroenterology 67, 748-750 (1974)

5. Creutzfeldt, W., Arnold, R., Creutzfeldt, C., Feurle, G., Ketterer, H.: Gastrin and G-cells in the antral mucosa of patients with pernicious anaemia, acromegaly and hyperparathyroidism and in a Zollinger-Ellison tumour of the pancreas. Europ. J. clin. Invest. 1, 461-479 (1971)

6. Dupré, J., Ross, S. A., Watson, D., Brown, J. C.: Stimulation of Insulin secretion by gastric inhibitory polypeptide in man. $J$. clin. Endocr. 37, 826-828 (1973)

7. Falko, J. M., Crockett, S. E., Cataland, S., Mazzaferri, E. L.: Gastric inhibitory polypeptide (GIP) stimulated by fat ingestion in man. J. clin. Endocr. 41, 260-265 (1975)

8. Hunter, W. M., Greenwood, F. C.: Preparation of ${ }^{131}$ I-labelled human growth hormone of high specific activity. Biochem. J. 89, 114-123 (1963)

9. Joffe, B. I., Bank, S., Jackson, W. P. U., Vinik, A. I., Keller, P.: Effects of intravenous tolbutamide on serum insulin levels in pancreatic diabetes. Diabetes 18, 499-501 (1968)

10. Kalk, W. J., Vinik, A. I., Bank, S., Hayes, J. R., Ardill, J., Buchanan, K. D., Keller, P., Jackson, W. P. U.: Plasma gastrin responses to arginine in chronic pancreatitis. Diabetes $\mathbf{2 3}$, 264-267 (1974)

11. Kuzio, M., Dryburgh, J. R., Malloy, K. M., Brown, J. C.: Radioimmunosassay for gastric inhibitory polypeptide. Gastroenterology 66, 357-364 (1974)

12. Mayer, G., Arnold, R., Feurle, G., Fuchs, K., Ketterer, H., Track, N. S., Creutzfeldt, W.: Influence of feeding and sham feeding upon serum gastrin and gastric acid secretion in control subjects and duodenal ulcer patients. Scand. J. Gastroent. 9, 703-710 (1974)

13. Melani, F., Ditschuneit, H., Bartelt, K. M., Friedrich, H., Pfeiffer, E. F.: Uber die radioimmunologische Bestimmung von Insulin im Blut. Klin. Wschr. 43, 1000-1007 (1965)

14. Pederson, R. A., Schubert, H. E., Brown, J. C.: Gastric inhibitory polypeptide. Its physiologic release and insulinotropic action in the dog. Diabetes 24, 1050-1056 (1975).

15. Polak, J. M., Pearse, A. G. E., van Noorden, S., Bloom, S. R., Rossiter, M. A.: Secretin cells in coeliac disease. Gut 14, 870-874 (1973)

16. Polak, J. M., Bloom, S. R., Kuzio, M., Brown, J. C., Pearse, A. G. E.: Cellular localization of gastric inhibitory poly-peptide in the duodenum and jejunum. Gut 14, 284-288 (1973)

17. Rehfeld, J. F., Stadil, F., Baden, H., Fischerman, K.: The enteral insulin-stimulation after Whipple's operation. Diabetologia 11, 207-210 (1975)

18. Stern, D. H., Walsh, J. H.: Gastrin release in postoperative ulcer patients: Evidence for release of duodenal gastrin. Gastroenterology 64, 363-369 (1973)

Received: March 31, 1976, and in revised form: April 23, 1976

Prof. W. Creutzfeldt

Division of Gastroenterology

and Metabolism

Dept. of Medicine

Univ. of Göttingen

Humboldtallee 1

3400 Göttingen

Federal Republic of Germany

Responsible for the text: Prof. Dr. W. Creutzfeldt, Med. Universitätsklinik, Humboldtallee 1, D-34 Göttingen

Prof. Dr. K. Schöffling, Zentrum der Inneren Medizin, Theodor-Stern-Kai 7, D-6 Frankfurt 70

Responsible for advertisements: L. Siegel, G. Martin, Kurfürstendamm 237, D-1000 Berlin 15, Springer-Verlag Berlin-Heidelberg-New York, Printed in

Germany by aprinta, Wemding 